\title{
Pengaruh Alokasi Pajak Antarperiode dan Likuiditas Terhadap Kualitas Laba pada Perusahaan Pertambangan
}

\author{
Wastam Wahyu Hidayat \\ ${ }^{1}$ Fakultas Ekonomi dan Bisnis Universitas Bhayangkara Jakarta Raya
}

\begin{tabular}{l}
\hline ARTICLE INFO \\
\hline Article History: \\
Received Oct $3^{\text {th }}, 2020$ \\
Revised July $27^{\text {th }}, 2021$ \\
Accepted Aug $13^{\text {th }}, 2021$
\end{tabular}

Keywords:

Alokasi pajak;

Likuiditas;

Kualitas laba;

Perusahaan;

Pertambangan.

\begin{abstract}
This research aims to examine the effect of tax allocation between periods, and liquidity on earnings quality by proxying Discretionary Accruals. This study uses a quantitative approach. The population in this study were mining companies listed on the Indonesia Stock Exchange (IDX) during 2012 - 2017. The sampling method used was purposive sampling. Purposive sampling is a technique with certain considerations or that meets certain criteria so that the samples that can be taken in this study are 12 mining companies from a total population of 46 mining companies. Data analysis in this study used multiple linear regression analysis. In order to obtain unbiased test results, the classical assumption test is first carried out, then the model feasibility test is carried out. The results showed that partially at the 0.05 percent confidence level, the inter-period tax allocation variable partially had no effect on earnings quality with the DACC proxy because sig was greater than 0.05 , i.e. 0.638 . The liquidity variable partially has no significant effect on earnings quality because Sig is greater than 0.05 ie, 0.133, and Taken together, the Tax Allocation Variable between periods and Liquidity has no effect on Earnings Quality because Sig is greater than 0.05 ie, 0.319 .
\end{abstract}

\begin{abstract}
Penelitian ini bertujuan untuk menguji pengaruh alokasi pajak antarperiode, dan likuiditas terhadap kualitas laba dengan proxy Discretionary Acruals. Penelitian ini menggunakan pendekatan kuantitatif. Populasi dalam penelitian ini adalah perusahaan pertambangan yang terdaftar di Bursa Efek Indonesia (BEI) selama tahun 2012 - 2017. Metode pengambilan sampel yang digunakan adalah purposive sampling. Purposive sampling merupakan suatu teknik dengan pertimbangan tertentu atau yang memenuhi kriteria tertentu, sehingga sampel yang dapat diambil dalam penelitian ini adalah 12 perusahaan pertambangan dari total populasi 46 perusahaan pertambangan. Analisis data dalam penelitian ini menggunakan analisis regresi linier berganda. Untuk mendapatkan hasil pengujian yang tidak bias, pertama-tama dilakukan pengujian asumsi klasik, kemudian dilakukan pengujian kelayakan model. Hasil penelitian menunjukkan bahwa secara parsial pada tingkat keyakinan 0,05 persen, Variabel alokasi pajak antar periode secara parsial tidak berpengaruh terhadap kualitas laba dengan proksi DACC karena sig lebih besar dari 0.05 yaitu, 0.638 . Variabel likuiditas secara parsial tidak berpengaruh signifikansi terhadap kualitas laba karena Sig lebih besar dari 0.05 yaitu, 0.133 dan Secara bersama-sama Variabel Alokasi Pajak antara periode dan Likuiditas tidak berpengaruh terhadap Kualita Laba, karena Sig lebih besar dari 0.05 yaitu, 0.319 .
\end{abstract}

(c) (1) (c) 2020 The Author(s). Published by Universitas Indraprasta PGRI, Jakarta, Indonesia. This is an open access article under the CC BY license (https://creativecommons.org/licenses/by/4.0/)

\section{Corresponding Author:}

Wastam Wahyu Hidayat

Email: wastam.wahyu@dsn.ubharajaya.ac.id

How to Cite: Hidayat, W.W. (2021).Pengaruh alokasi pajak antar periode dan likuiditas terhadap kualitas laba pada perusahaan pertambangan. Sosio e-Kons, 13 (2), 116-121.http://dx.doi.org/ 10.30998/sosioekons.v13i2.7649 


\section{PENDAHULUAN}

Teori pasar menunjukkan bahwa pasar akan bertransaki segera terhadap informasi baru. Pasar efisiensi memcerminkan keseimbangan harga dan memberikan informasi kepada investor dan calon investor pada saat tertentu dibutuhkan. Berdasarkan sejarah, sejak tahun 1880 kegiatan jual beli saham dan juga jual beli obligasi telah terjadi di indonesia. Tujuan dari kegiatan itu adalah untuk memperoleh sumber dana sebagai pembiayaan dalam rangka usaha atau bisnis. Kegiatan ini adalah kegiatan pasar modal. Oleh karena itu peran pasar modal harus memberikan informasi yang relevan karena informasi yang jelas dan relevan kepada investor dan calon investor, menunjukkan pelayanan yang optimal dan efisiensi, terkait informasi harga skuritas dan lain sebagainya. Salah satu informasi yang tersedia yang dibutuhkan oleh masyarakat umum baik calon investor maupun investor adalah kaitannya dengan informasi laporan keuangan yang dibuat oleh perusahaan (Nurhanifah \&Jaya,2014).

Financial Report adalah hasil laporan yang dibuat oleh perusahaan yang digunakan manajemen untuk memberikan informasi kepada pihak luar perusahaan sebagai pertimbangan untuk melakukan investasi. Informasi laba yang diinformasikan di Financial Report merupakan salah satu indikator penilai kinerja perusahaan sekaligus menjadi dasar dalam rangka keputusan yang akan diambil. Para pengguna Financial Report selalu ingin memperoleh profit yang baik/besar. Oleh karena itu, terjadi perbedaan antara pihak calon investor dan investor dengan pemilik perusahaan, sehingga ada penafsiran bawa informasi yang ada di Financial Report kurang akurat (Eka Oktaraya, 2014).

Menurut Hery (2015), laporan keuntungan dan kerugian perusahaan adalah sebagian dari Finance Report dimana menyajikan tentang kondisi keuangan perusahaan yang yang disajikan pada periode tertentu (Bulanan). Dengan laporan laba rugi, maka penanam modal mendapatkan informasi berkaitan dengan kondisi operasional perusahan terutama tingkat profitabilas yang akan diperoleh penenam modal. Melalui Laporan Keuntungan dan kerugian ,para pemberi pinjaman akan melalukan beberapa langkah untuk menganalisis kesiapan dan kesanggupan tentang mampu atau tidak dalam membayar kredit. Bersarnya pajak yang ditetapkan dalam Financial Report yang menginformasikan keuntungan perusahaan akan membayarkan pajaknya ke Kas Negara. Kepentingan yang berbeda antara pimpinan perusahaan dengan penanam modal (pemegang saham) dapat menyebabkan terjadi konflik kepentingan. Padahal kedua pihak mempunyai kepentingan yang sama yaitu mendapatkan keuntungan yang tinggi. Namun, pihak pengelola perusahaan kadang menginginkan keuntungan pada diri sendiri, sehingga informasi-informasi yang disampaikan ke pihak penanam modal (pemegang saham) tidak transfaran yang mengakibatkan kualitas laba menjadi rendah (Halimatus Saidah, 2015). Berdasarkan Agency Teory, permasalahan yang ada di perusahaan mampu diatasi dengan meningkatkan laba yang berkualitas sebagai tolok ukur untuk menganalisis kualitas pelaporan keuangan. Tingginya kualitas pelaporan keuangan berasal dari tingginya kualitas Financial Report, bahwa laba yang berkualitas adalah laba yang dilaporkan sesuai dengan kondisi nyata perusahaan dan mampu memprediksi kualitas laba yang akan datang dengan analisis yang tepat bagi perusahaan dan persistensi laba yang baik. Suatu perusahaan berkualitas laba yang baik apabila laba yang diinformasikan dalam Financial Report adalah laba yang sebenarnya terjadi dan mencerminkan kinerja keuangan perusahaan yang sebenarnya (Halimatus Saidah, 2015).

Kualitas laba dicatat berdasarkan pada hubungan laba kas Accrual yang dapat diukur dengan berbagai ukuran, yaitu: rasio kas operasi dengan laba, perubahan accrual total, estimasi abnormal atau discretionary accruals (Accrual abnormal atau DA), dan estimasi hubungan Accrual kas. Dengan menggunakan Analisis rasio Cash Flow operasi dengan laba, maka kualitas laba dapat ditunjukan melalui pendekatan laba dengan Cash flows operasi. Laba yang semakin dekat dengan Cash flows operasi mengindikasikan laba yang semakin berkualitas. Dengan menggunakan ukuran perubahan accrual total, laba yang berkualitas adalah laba yang mempunyai perubahan accrual total kecil. Pengukuran ini dapat diasumsikan bahwa perubahan total accrual diakibatkan dengan adanya perubahan discretionary,accruals. Estimasi discretionary accruals dapat diukur secara langsung untuk 
menentukan kualitas laba. Semakin kecil discretionary accruals semakin tinggi kualitas laba dan sebaliknya (Halimatus Saidah, 2015).

Alokasi pajak antarperiode (interperiod tax allocation) adalah pengalokasian pajak penghasilan atar periode tahun buku yang satu dengan periode - periode tahun buku berikutnya atau sesudahnya. Interperiod tax allocation merupakan hasil penerapan konsep akuntansi Accrual yang tercermin dari jumlah beban dan penghasilan pajak tangguhan yang dilaporkan Bersama-sama dengan beban pajak kini dalam laporan laba rugi Perusahaan (Nurhanifah \&Jaya,2014).

Rasio likuiditas (liquidity ratio) yaitu suatu keadaan dimana perusahaan mampu untuk memenuhi kewajiban (utang) jangka pendek secara tepat waktu. Apabila perusahaan mampu memenuhi kewajiban (utang) lancarnya yang makin tinggi dimana bila jumlah aset lancar lebih besar daripada kewajiban (utang) lancar yang dimilikinya, jadi, dapat disimpulkan bahwa perusahaan telah mampu memenuhi kewajiban (utang) lancarnya. Apabila perusahaan mampu membayar kewajiban (utang) jangka pendek yang dimilikinya maka informasi laporan Keuangan yang dihasilkan perusahaan merupakan laba yang berkualitas atau laba yang sesungguhnya.

Perusahaan dengan rasio lancar tinggi akan memiliki risiko yang relatif kecil sehingga kreditur merasa yakin dalam memberikan pinjaman kepada perusahaan, dan calon Investor/investor akan tertarik untuk membeli saham ke perusahaan tersebut karena calon investor/investor yakin bahwa perusahaan mampu bertahan secara berkelanjutan. Dengan demikian pada saat laba dipublikasikan, pasar akan merespon positif laba tersebut. Rasio likuiditas yang digunakan adalah current ratio (Current asset/Current Liability). Current ratio yang tinggi menunjukkan tidak terjadi masalah dalam likuiditas karena current asset perusahaan tinggi, sehingga semakin tinggi likuiditas artinya laba yang dihasilkan suatu perusahaan berkualitas karena manajemen perusahaan tidak perlu melakukan praktik manajemen laba (Paulina Warianto,2014).

Adanya masalah terkait kualitas laba dan tidak konsistennya beberapa hasil penelitian, maka peneliti terdorong untuk melakukan penelitian yang bertujuan untuk melihat pengaruh terhadap kualitas laba.

\section{METODE}

Dalam penelitian ini, metode yang digunakan adalah kuantitatif yang menyajikan data penelitian menggunakan angka-angka. Metode pengumpulan data yang dilakukan dalam penelitian ini adalah data sekunder yang berasal dari laporan keuangan 12 perusahaan tambang yang terdaftar di Bursa Efek Indonesia (BEI) periode 2012 - 2017. Dalam penelitian ini sebagai variabel independen yaitu Alokasi Pajak Antarperiode, dan Likuiditas dan variable independen adalah Kualitas Laba.

\section{HASIL DAN PEMBAHASAN}

Tabel 1.

Model Summary

\begin{tabular}{cccccc}
\hline $\mathrm{A}$ & $\mathrm{R}$ & $\mathrm{R}$ Square & Adjust R Square & F-Change & Sig .F Change \\
\hline Sumber: Data di olah penulis & 0.033 & 0.004 & 1.160 & $0.319 \mathrm{~b}$ \\
\hline
\end{tabular}

Berdasarkan Tabel.1 Model Summary bahwa koefisien determinasi (R2) Alokasi Pajak Antarperiode, dan Likuiditas didapat nilai $R$ square sebesar 0,033 atau 3,3\% sehingga menunjukkan bahwa persentase sumbangan pengaruh variabel independen yaitu Alokasai Pajak Antarperiode, dan Likuiditas terhadap variabel dependen Kualitas Laba sebesar 3,3\%. Sedangkan sisanya $(100 \%-3,3 \%$ $=95,7 \%$ ) dipengaruhi oleh variabel lain di luar model regresi ini.Sedangkan hasil Uji silmutan ( Uji F) 
diperoleh nilai signifikansi sebesar 0.319 lebih besar dari 0.05 sehingga secara simultanvariabel alokasi pajak antar periode dan likuidasi tidak berpengaruh terhadap Kualitas laba.

Tabel.2.

Koefisien

\begin{tabular}{cccccc}
\hline \multirow{2}{*}{ Model } & & \multicolumn{4}{c}{ Unstandardized } \\
Coefficients \\
\cline { 2 - 6 } & & $\mathrm{B}$ & Std Error & $\mathrm{t}$ & $\mathrm{sig}$ \\
\hline \multirow{2}{*}{1} & Constan & -0.5560 & 0.095 & 5.847 & 0.000 \\
& Alokasi Pajak & 0.047 & 0.100 & 0.473 & 0.638 \\
& Likuiditas & 0.074 & 0.040 & 1.522 & 0.133 \\
\hline
\end{tabular}

Sumber: data di olah penulis

Berdasarkan Tabel 2 koefisien di atas menunjukkan bahwa, Hasil output koefisien variabel Alokasi Pajak Antarperiode nilai signifikan 0,638 >0,05. Dengan demikian secara parsial Variabel alokasi pajak antara periode tidak berpengaruh terhadap Kualitas Laba. Hasil penelitian ini yang mengukur beban (penghasilan) pajak tangguhan tidak berpengaruh terhadap kualitas laba dengan pengukuran DACC. Alasan mengapa pelaporan beban dan penghasilan pajak tangguhan tidak berpengaruh terhadap kualitas laba menggunakan proksi DACC. Hal ini dikarenakan investor menyadari bahwa beban (penghasilan) pajak tangguhan yang dilaporkan di dalam laporan laba rugi merupakan hasil dari akuntansi Accrual. Di samping itu beban (penghasilan) pajak tangguhan yang dilaporkan dalam laporan laba-rugi merupakan komponen transitori atau komponen yang bersifat sementara. Dengan kesadaran tersebut, investor akan memahami bahwa kenaikan atau (penurunan) laba akuntansi hanyalah akibat dari pengakuan konsekuensi pajak karena adanya perbedaan temporer nilai tercatat aktiva dan kewajiban berdasarkan ketentuan akuntansi dan perpajakan. Hasil ini sesuai dengan penelitian yang dilakukan oleh ( Nurhanifah \& jaya (2014) dengan judul pengaruh alokasi pajak antarperiode dan likuiditas terhadap kualitas laba, yang menyatakan bahwa alokasi pajak antarperiode tidak berpengaruh terhadap kualitas laba (discretionary accruals) dikarenakan baik beban maupun penghasilan pajak tangguhan yang di laporkan dalam laporan laba rugi dipandang sebagai gangguan persepsian, sebagai pengaruh dari akuntansi Accrual dalam pengakuan pendapatan dan beban serta peristiwa lain yang memiliki konsekuensi pajak.

Menurut Tabel 2 koefisien menunjukkan bahwa, hasil output koefisien variabel Alokasi Likuiditas nilai signifikan 0,133>0,05. Dengan demikian secara parsial Variabel Likuiditas tidak berpengaruh terhadap Kualitas Laba. Variabel likuiditas tidak berpengaruh terhadap kualitas laba dapat dilihat dari semakin tinggi likuiditas perusahaan maka akan mengurangi kualitas laba. Apabila tingkat likuiditas suatu perusahaan terlalu tinggi, artinya perusahaan tersebut tidak mampu untuk mengelola aktiva lancarnya semaksimal mungkin, sehingga kondisi kinerja keuangan perusahaan tidak baik. Kinerja keuangan perusahaan yang tidak baik akan mengakibatkan perusahaan tersebut akan memanipulasi labanya guna memperbaiki informasi laba pada laporan keuangan perusahaan dengan tujuan untuk menarik perhatian investor agar menginvestasikan dananya pada perusahaan tersebut. Hal ini akan berdampak negatif bagi investor. Oleh karena itu investor memberikan respons yang negatif terhadap perusahaan yang memiliki tingkat likuiditas yang relatif tinggi. Hasil ini sesuai dengan penelitian yang dilakukan oleh (Saidah ,2015) dengan judul pengaruh leverage, likuiditas, size, pertumbuhan laba dan IOS terhadap kualitas laba, yang menyatakan bahwa likuiditas tidak berpengaruh signifikan terhadap kualitas laba (discretionary accruals). Dikarenakan distribusi rata-rata likuiditas termasuk dalam kriteria kurang liquid. Apabila tingkat likuiditas suatu perusahaan terlalu tinggi, artinya perusahaan tersebut tidak mampu untuk mengelola aktiva lancarnya semaksimal mungkin, sehingga kondisi kinerja keuangan perusahaan tidak baik, yang akan mengakibatkan perusahaan tersebut melakukan memanipulasi labanya guna mempercantik informasi laba pada laporan keuangan perusahaan. Oleh karena itu investor akan memberikan respons yang negatif terhadap perusahaan yang memiliki tingkat likuiditas yang relatif tinggi. 


\section{SIMPULAN DAN SARAN}

Berdasarkan hasil analisis data dan pembahasan yang telah di sampaikan di atas dapat disimpulkan bahwa variabel alokasi pajak antarperiode secara parsial tidak berpengaruh terhadap kualitas laba dengan proksi DACC. Variabel likuiditas secara parsial tidak berpengaruh signifikansi terhadap kualitas laba dan Secara bersama-sama variabel alokasi pajak antaraperiode dan likuiditas tidak berpengaruh terhadap Kualita Laba. Penelitian ini diharapkan bisa membantu setiap perusahaan pertambangan untuk menjalankan manajemen keuangan yang lebih baik dan hati-hati, serta melakukan analisis yang baik terhadap alokasi pajak antarperiode dan likuiditas dengan benar sehingga meningkatnya kualitas laba serta dapat dipercaya oleh masyarakat dan investor.

\section{ACKNOWLEDGEMENT}

Terimakasih kepada Universitas Indraprasta PGRI, Jakarta, Indonesia dan khususnya Tim Jurnal Sosio e-kons yang memberikan kesempatan kepada saya untuk memublikasikan paper saya, semoga paper saya dapat berguna bagi masyarakat, serta Jurnal Sosio e-kons terus maju dan sukses selalu.

\section{REFERENCES/DAFTAR PUSTAKA}

Aditama.F \& Purwaningsih.A. (2014). Modus.Pengaruh Perencanaan Pajak Tehadap Manajemen Laba Pada Perusahaan Non Manufaktur yang Terdaftar di Bursa Efek Indonesia,Jurnal Modus Vol 26 No 1,33-50

Amalia,Nurul. (2017). Pengaruh Alokasi Pajak Antar Periode dan Likuiditas Terhadap Kualitas Laba Studi Kasus pada Perusahaan Pertambangan yang Terdaftar di ursa Efek Indonesia Tahun 2012-2016 Skripsi : Universitas Bhayangkara Jakarta Raya.

Harahap,S.S. (2015).Teori Akuntansi. Edisi Revisi 2011.Jakarta:Rajawali

Heri.(2015).Analisis Kinerja Manajemen,Jakarta. Grasindo

Ilyas,W.B dan Priantara,D.(2015). Akuntansi Perpajakan.Jakarta Mitra Wacana Media. Terapan Berbasis Standar Akuntansi \& Ketentuan Pajak Terbaru.Yogyakarta:ANDI.

Ilyas,W.B dan Priantara,D. (2015). Akuntansi Perpajakan. Jakarta:Penerbit ,Mitra Wacana Media.

Kasmir. (2014). Analisis Laporan Keuangan".Penerbit Jakarta:Rajawali.

Kurniawan,Albert. (2014). Metode Riset untuk Ekonomi \& Bisnis, Teori untuk Konsep \& Praktik“ Penelitian Bisnis. Penerbit ,Bandung:Alfabeta.

Lubis,Irsan. (2015). Mahir Akuntansi,Pajak Terapan Berbasis Standar Akuntansi dan Ketentuan Pajak terbaru,Yogyakarta : Andi

Nurhanifah, Y.A dan Jaya, T.E. (2014). Pengaruh Alokasi Pajak Antar Periode,Investment Opportunity Set dan Likuiditas Terhadap Kualitas Laba, Jurnal IImiah Wahana Akuntansi Vol 9 No 2,109133.

Oktaraya.E, Syafitri.L, dan Wijaya (2014). Pengaruh pertumbuhan laba,Invesment opportunity set,leverage perusahaan terhadap Kualitas laba pada perushaan yang terdaftar di BEl" Skripsi-Univ.Bahyangkara Jakarta Raya

Romasari,Sonya. (2014). Pengaruh Persistensi Laba, Struktur Modal, Ukuran Prusahaan, dan Alokasi Pajaka ntar Periode Terhadap Kualitas Laba Studi Empiris pada Perusahaan Manufaktur yang Terdaftar di BEl).Jurnal Akuntansi dan Keuangan Vol.16.no.1. 1-32.

Saidah.H dan Priyadi,M.P. (2015). Pengaruh Leverage, Likuiditas,Size , Pertumbuhan Laba dan IOS "Jurnal IImu dan Riset Akuntansi Vol.4.No.5 1-21 
Sukmawati.S, Kusmuriyanto dan Agustina.L. (2014). Pengaruh Struktur Modal, Ukuran Perusahaan, Likuiditas dan Return On Asset Terhadap Kualitas Laba Jurnal Analisis Akuntansi Vol 3 No 1,26-33.

Sugiyono.Adan Untung.E. (2016). Analisis Laporan Keuangan, Jakarta : Grasindo

Sugiyono. (2016). Metode Penelitian Kantitatif, Kualitatif dan R \& D, bandung, Alfabet.

Sujarweni,Wiratna.(2014). Metodologi Penelitian .Yogyakarta : Pustaka Baru Press.

Waluyo.2014.Akuntansi Pajak Edisi 5.Jakarta:Salemba Empat.

Warianto,Paulina.2014.Pengaruh Ukuran Perusahaan,Struktur Modal,Likuiditas dan Invesment Opportunity (IOS) terhadap Kualitas Laba, Jurnal Modus Vol.26.no.1,19-32

Yadiati.W dan Mubarok.A.2017. "Kualitas Pelaporan Keuangan Kajian Teoritis dan Empiris". prenada media kencana group, Vol.1, 1-200 